\title{
STUDI KASUS MANAJEMEN SEKOLAH INKLUSI SDN MANAHAN SURAKARTA
}

\author{
Ahmad Hafizh ${ }^{1 *}$, Herry Widyastono ${ }^{2}$, Sunardi $^{3}$ \\ ${ }^{123}$ Universitas Sebelas Maret Surakarta, Indonesia \\ Email:ahafizh91@gmail.com*, herrywidyastono@staff.uns.ac.id ${ }^{2}$, \\ sunardi.ipuns@gmail.com ${ }^{3}$
}

\section{INFORMASI ARTIKEL}

Terkirim 23-Mei-2020

Revisi 18-Sep-2020

Diterima 29-Nov-2020

\section{Kata kunci:}

Schools of Inclusion,

Management, Quality of

Education, Children with

Special Needs

\begin{abstract}
ABSTRAK
Inclusive education is one form of special education in Indonesia to provide opportunities for children with special needs to get an education. But the reality faced by inclusive schools in management and implementation has not been satisfactory. Many things are not in accordance with predetermined standards. In this study using a qualitative approach with a case study design. The research technique was carried out by non-participant observation, in-depth interviews and documentation studies. The results obtained show that the management of inclusive schools is still unsatisfactory such as the lack of facilities and accessibility of children with special needs, special educators, special assistant teachers. This will certainly affect the quality of education, learning processes, and evaluations carried out so that certain stages also have an impact on the outputs and outcomes of students with special needs.
\end{abstract}

(7) (2) This is an open access article distributed under the Creative Commons 4.0 Attribution License, This license lets others remix, tweak, and build upon your work even for commercial purposes, as long as they credit you and license their new creations under the identical terms @2018 by author and Universitas Negeri Padang.

\section{Pendahuluan}

International Education for All (EFA) oleh UNESCO tahun 2000 menjadi salah satu dasar pemerintah dalam memberikan kebijakan wajib belajar pendidikan dasar sembilan tahun. Tujuan untuk menegaskan bahwa semua anak, remaja, dan orang dewasa tak terkecuali anak berkebutuhan khusus mempunyai hak atau kesempatan yang sama dalam memperoleh manfaat dari proses pendidikan.

Sesuai dengan Undang-Undang Dasar (UUD) 1945 pasal 31 Ayat 1 yang menjelaskan bahwa setiap warga negara memiliki kesempatan yang sama, dilanjutkan dengan Undang-Undang nomor 4 tahun 1997 pasal 5 ayat 1 terkait anak berkebutuhan khusus yang berhak memperoleh pendidikan pada semua satuan, jalur, jenis, dan jenjang. Dan pada Undang-Undang nomor 20 tahun 2003 yang menyatakan anak berkebutuhan khusus berhak memperoleh pendidikan khusus. Maka sudah semestinya ada penyelenggaraan pendidikan yang mampu dan siap untuk menerima dan mendidik peserta didik anak berkebutuhan khusus. Namun pada kenyataannya pendidikan di Indonesia sekarang belum mampu menjangkau semua hambatan dan usia sekolah untuk mendapatkan akses pendidikan yang bermutu.

Undang-Undang nomor 20 tahun 2003 pasal 32 yang menyebutkan tentang sistem pendidikan nasional mengenai Pendidikan Khusus dan Pendidikan Layanan Khusus memiliki banyak bentuk dalam memberikan pendidikan bagi anak berkebutuhan khusus maupun masyarakat lainnya dengan berbagai model pendidikan, yang salah satunya adalah sekolah inklusi. Sekolah inklusi menjadi salah satu bentuk konkrit dalam pengimplementasian pedidikan untuk semua dan menjadi salah satu topik 
yang mulai dibicarakan oleh masyarakat Indonesia. Hal tersebut menjadikan perlunya pengembangan dan peningkatan mutu pendidikan inklusi guna memenuhi hak pendidikan bagi seluruh warga terlebih dengan tidak membeda-bedakan lingkungan sosialnya.

Tentu pengelolaan sekolah inklusi berbeda dengan sekolah biasa, terlebih dalam hal manajemen sekolah yang didalamnya terdapat berbagai unsur seperti kurikulum, peserta didik, pendidik, sarpras, dll. Saat ini pelaksanaan dari pendidikan sekolah inklusi banyak mengacu pada pelaksanaan dan manajemen pendidikan sekolah reguler yang kemudian ada sedikit modifikasi sehingga dapat mengakomodasi kemampuan dan kebutuhan anak berkebutuhan khusus. Menurut Tarmansyah (2007:144) menyatakan bahwa pada dasarnya tidak ada manajemen organisasi yang khusus untuk pendidikan inklusi di Indonesia, makanya untuk menyesuaikan program kegiatan sekolah dilakukan modifikasi yang sifatnya praktis dan fleksibel di sekolah inklusi.

Peningkatan mutu pendidikan pada dasarnya dipacu oleh kebijakan dan dukungan dari pemerintahan, akan tetapi faktor utama dalam peningkatan mutu pendidikan adalah faktor tenaga pendidik dan kependidikan yang secara langsung berinteraksi dengan subjek pendidikan atau peserta didik. Pendapat Dien (1973: 134) mengatakan bahwa pendidikan yaitu pihak yang mendidik, pihak yang memberikan anjuran-anjuran, norma-norma, dan berbagai macam pengetahuan dan kecakapan, pihak yang turut membatu menghumanisasikan anak. Sedangkan menurut Heriawan dan Nugroho (1988: 430) bahwa pendidikan meliputi: orang dewasa, orang tua, guru, pemimpin masyarakat, pemimpin agama. Realita yang dihadapi kualitas guru pada sekolah inklusi jauh dari kebutuhan yang ada. Tidak hanya pada kualitas guru dalam kepahaman dan kemampuan mendidik anak berkebutuhan khusus, namun juga komponen pelengkapnya seperti guru pendamping, dst yang kurang atau bahkan tidak tersedia.

Selain pendidik dan kependidikan, kurikulum pembelajaran menjadi unsur penting dalam pendidikan. Kurikulum secara teknis seperti kegiatan pembelajaran dikelas maupun diluar kelas dengan adanya administrasi pelengkap seperti RPP, Silabus, dan sejenisnya. Seperti pendapat Crow and Crow (dalam Hamalik, 1987) kurikulum adalah rancangan pengajaran atau sejumlah mata pelajaran yang disusun secara sistematis untuk menyelesaikan suatu program untuk memperoleh ijazah. Terkait hal tersebut jelas bahwa sekolah inklusi dengan adanya anak berkebutuhan khusus sebagai peserta didik maka ada perbedaan dengan kurikulum pada sekolah reguler. Penerapan modifikasi dalam dilakukan secara langsung oleh sekolah tersebut untuk keseluruhan proses pembelajaran disekolah maupun dengan inisiatif guru kelas.

Manajemen sekolah secara keseluruhan dikendalikan, dikontrol, dan diawasi oleh kepala sekolah sebagai kepala manajer dari sekolah tersebut. Sesuai pendapat Rossow (dalam Astuti, 2011: 49) bahwa kepala sekolah inklusi sangat penting untuk memahami prinsip pelaksanaan pendidikan inklusi dan disiplin ilmu pendidikan kebutuhan khusus, sehingga aktifitas yang dijalankan sebagai kepala sekolah benar-benar berakar dari filosofi pendidikan inklusi. Mulai dari input, proses, outpun bahkan mungkin outcome yang ada. Selain itu kepala sekolah juga berperan sebagai supervisi dan motivator bagi seluruh unsur sekolah maupun lingkungan sekolah.

Segala unsur dan komponen manajemen sekolah selain yang telah dibahas sebelumnya juga berperan penting dalam keberjalanan dan kelancaran operasional serta manajemen sekolah. Apabila salah satu komponen tersebut tidak optimal dan tidak berjalan sesuai dengan fungsinya, maka pengelolaan manajemen sekolah menjadi kurang efektif dan pembelajaran kurang optimal.

\section{Metode}


Pendekatan yang digunakan dalam penelitian ini adalah pendekatan kualitatif dengan rancangan studi kasus. Menurut Tellis (1997) metode studi kasus memiliki unit analisis yang lebih mengacu pada sistem tindakan yang dilakukan dibanding pada individunya sendiri atau suatu lembaga tertentu. Data dan sumber data dari hasil wawancara mendalam pada informan, data arsip dan dokumen untuk meunnjang data utama. Teknik penelitian dilakukan dengan observasi non partisipan, wawancara mendalam dan studi dokumentasi. Teknik analisis data dilakukan dengan interaktif.

\section{Hasil Penelitian dan Pembahasan}

Manajemen inklusi yang dilakukan menganut Surat Keputasan Dinas Pendidikan Surakarta Tahun 2008 dimana Sekolah Manahan ditunjuk menjadi salah satu sekolah inklusi yang berlanjut hingga sekarang. Pedoman pelaksanaan pembelajaran menggunakan kurikulum 2013 yang dilakukan modifikasi menyesuaikan kondisi dan kebutuhan terutama untuk peserta didik berkebutuhan khusus sehingga dapat mengakomodasi kebutuhan dan kemampuan yang dimiliki. Tujuan pembelajaran untuk peserta didik berkebutuhan khusus di sekolah ini diutamakan pada aspek sosial.

Beberapa modifikasi yang dilakukan diantaranya: (1) penilaian dan evaluasi pembejalaran, dengan memberikan standar penilaian yang berbeda untuk peserta didik berkebutuhan khusus menyesuaikan dengan kemampuan yang dimiliki sesuai dengan hasil indentifikasi dan asesmen yang telah dilakukan serta memberikan layanan khusus berupa ruang khusus dengan guru pendamping terutama disaat pelaksanaan ujian nasional. (2) kenaikan kelas, sesuai dengan penilaian dan evaluasi maka sistem kenaikan kelas untuk peserta didik berkebutuhan khusus menyesuaikan kemampuan, kondisi dan standar penilaian yang telah ditentukan sebelumnya. (3) pelaksanaan ujian kelulusan, kebijakan sekolah memberikan kebebasan untuk peserta didik berkebutuhan khusus dapat memilih mengikuti atau tidak ujian nasional. Jika peserta didik memilih untuk mengikuti ujian nasional maka akan ada ruang khusus dan pendamping serta pengawas dari dinas pendidikan. Bahkan jika ada peserta didik yang memilih untuk mengikuti program kerja paket.

Pelaksanaan pembelajaran dengan menggunakan kurikulum 2013 tidak serta merta dilakukan tanpa melakukan modifikasi. Sekolah memberikan keleluasaan untuk setiap guru kelas untuk melakukan modifikasi, baik dalam hal pembejalaran, penilaian, dan hal lainnya. Sekolah tidak secara langsung memberikan program khusus untuk kelas secara keseluruhan maupun khusus untuk peserta didik tertentu. Beberapa bentuk modifikasi yang sering dilakukan oleh guru kelas seperti memberikan jam khusus atau tambahan belajar, melakukan kelas pull-out pada mata pelajaran tertentu.

Peningkatan kualitas SDM pendidik dan kependidikan sekolah ikut andil aktif dalam Kelompok Kerja Guru (KKG) Inklusi Surakarta. Kegiatan yang dilakukan dengan mengajukan perwakilan untuk dihadirkan dan mengikuti pelatihan maupun diskusi dengan sekolah inklusi lainnya. Disamping kegiatan KKG Sekolah Manahan tidak jarang diundang untuk mengikuti pelatihan dan pembekalan guru sekolah reguler maupun sekolah inklusi pada regional daerah, provinsi, maupun nasional.

Salah satu inisiatif sekolah selain mengandalkan kehadiran forum eksternal, sekolah mengadakan pelatihan dan pembekalan secara internal. Pelaksanaannya dengan menyampaikan hasil diskusi atau informasi yang didapatkan perwakilan dalam forum eksternal yang kemudian hasil tersebut didiskusikan internal sekolah dalam agenda workshop. Selain itu sekolah juga mengagendakan workshop dengan menghadirkan tenaga ahli seperti pendidikan luar biasa, spesialis anak, dll ke sekolahan.

Ketersediaan tenaga pendidik khusus internal yang menangani anak berkebutuhan khusus maupun inklusi pada tahun-tahun sebelumnya ada namun hanya 1 guru, dan pada tahun ajaran 2019/2020 tidak tersedia, hal ini disebabkan keluarnya guru pendidik khusus tersebut dari sekolah. 
Menurut Astuti (2011:96) bahwa guru pendamping khusus merupakan lulusan Pendidikan Luar Biasa atau S1 Psikologi atau Kependidikan yang telah mempeoleh pelatihan intensif dalam pendidikan khusus atau pernak mengajar anak berkebutuhan khusus dalam kelas pendidikan khusus. Untuk guru pendamping khusus, sekolah tidak menyediakan, hanya saja bagi orangtua yang menyediakan guru pendamping untuk anaknya dipersilahkan dan pada pelaksanaan ujian akan disediakan guru pendamping khusus yang ditunjuk dari guru kelas.

Penunjukkan Sekolah Manahan sebagai sekolah inklusi pada tahun 2008 ditindaklanjuti dengan baik oleh pihak sekolah, yang salah satunya dengan melakukannya kerjasama sekolah dengan jurusan pendidikan luar biasa UNS yang kemudian memberikan banyak saran, arahan, dan melakukan diskusi dalam implementasi serta konsep inklusi. Salah satu bentuk konkritnya dengan diundangnya dosen jurusan sebagai narasumber workshop sekolah, secara terbuka menerima observasi, survey, dan penelitian yang mahapeserta didik lakukan untuk peningkatan mutu pendidikan.

Penerimaan peserta didik anak berkebutuhan khusus terdapat perubahan dari tahun sebelumnya. Dimana pada tahun-tahun sebelumnya pendaftaran dilakukan mandiri oleh pihak sekolah dengan memberikan gelombang khusus bagi pendaftar anak berkebutuhan khusus yang kemudian peserta didik akan diberikan identifikasi dan asesmen sehingga diketahui hambatan dan kemampuannya, termasuk kemungkinannya untuk dapat mengikuti pembelajaran dalam sekolah inklusi. Namun untuk tahun ini peserta didik anak berkebutuhan khusus didapatkan langsung daftarnya dari PLA. Seluruh alur mulai dari pendaftaran, identifikasi, dan asesmen dilakukan oleh pihak PLA.

Data anak berkebutuhan khusus di Sekolah Manahn pada tahun ajaran 2019/2020 sebagai berikut: Kelas 1 terdapat 3 peserta didik, kelas 3 terdapat 2 peserta didik, kelas 4 tedapat 2 peserta didik, kelas 5 terdapat 4 peserta didik, dan kelas 6 terdapat 1 peserta didik. Jenis dari peserta didik anak berkebutuhan khusus didominasi keterlambatan belajar dan autis. Namun pada tahun ajaran sebelumnya sudah pernah meluluskan peserta didik tunarungu.

Lingkungan Sekolah Manahan dengan usianya sebagai sekolah inklusi yang lebih dari 10 tahun sudah secara otomatis terkondisikan, terlebih sekolah sering melakukan sosialisasi, pembekalan, dan pengikutsertaan peserta didiknya dalam kegiatan masyarakat sekitar. Sehingga lingkungan, dalam hal ini masyarakat sekolah paham dan dapat mendukung keberjalanan pendidikan inklusi yang berjalan.

\section{Kesimpulan}

Sekolah Manahan sebagai sekolah inklusi termasuk sebagai salah satu sekolah poinir di Kota Surakarta, namun pada kenyataannya keberjalanannya sebagai sekolah inklusi yang sudah lebih dari 10 tahun masih banyak kekurangannya. Seperti kurangnya tenaga pendidik khusus maupun fasilitas dan aksesibilitas anak berkebutuhan khusus. Memang tidak dapat dipungkiri bahwa selama ini sekolah menerima peserta didik yang didominasi oleh anak dengan keterlambatan belajar, namun tidak menutup kemungkinan kedepan akan ada perserta didik dengan ketunaan yang benar-benar membutuhkan aksesibilitas demi menunjang pembelajarannya dikelas.

Jika kita melihat standar sekolah inklusi yang tercantum pada buku Pendidikan Inklusif dan Perlindungan Anak maka hasil yang didapat Sekolah Manahan sebagai sekolah inklusif tidaklah memuaskan. Walaupun memang bukan berarti pelaksanaan pendidikan inklusifnya buruk, tetap menjadi sekolah yang baik jika melihat kondisi sekolah inklusi yang lain, akan tetapi secara standar resmi masih perlu perbaikan.

\section{Daftar Rujukan}


Astuti, I. (2011). Pakem Sekolah Inklus. Malang: Bayumedia Publishing.

Daien, A. I. K. (1973). Pengantar Ilmu Pendidikan. Malang : Usaha Nasional

Hamalik. O. (1987). Pembinaan Pengembangan Kurikulum. Bandung: Pustaka Martina.

Heriawan. A, Nugroho. D. H. (1988). Mengenal Manusia dan Pendidikan. Yogyakarta: Liberty

Tarmansyah. (2007). Pendidikan Inklusi Untuk Semua. Jakarta: Departemen Pendidikan Nasional

Tellis. W. M. (1997). Introduction to Case Study. The Qualitative Report, 3(2), 1-14. Retrieved.https://nsuworks.nova.edu/tqr/vol3/iss2/4/ diakses pada 22 Mei 2020 pukul 17:15 WIB

Undang-Undang Republis Indonesia Nomor 20 Tahun 2003 Tentang Sistem Pendidikan Nasional. $\quad$ http://peraturan.bpk.go.id/home/detail/43920/uu-no-20-tahun-2003. Diakses pada 5 Mei 2020, pukul 20.39 